Oualid Abidi', ${ }^{1}$ Vladimir Dzenopoljac ${ }^{2 *}$, Aleksandra Dzenopoljac ${ }^{3}$ ${ }^{1}$ School of Business, Australian College of Kuwait ${ }^{2}$ College of Business and Economics, United Arab Emirates University ${ }^{3}$ Independent Researcher, Kuwait

\title{
Discussing the Role of Entrepreneurial Universities in COVID-19 Era in the Middle East
}

DOI:10.7595/management.fon.2021.0014

Abstract:

Research Question: This conceptual research explores the role that academic entrepreneurship can play in Middle Eastern countries in addressing the effects of COVID-19 pandemic in the region. Motivation: Entrepreneurial universities are pivotal in contemporary economic systems due to their significant contributions in innovation efforts. Part of their mission is seen in the commercialization of their scientific knowledge through the creation of spin-offs (Cvijic et al., 2019; O'shea et al., 2005; Rodrigues et al., 2019). The challenges and constraints imposed by the COVID-19 pandemic have demonstrated the importance of coordinating the efforts of all parties including those of entrepreneurial universities in order to develop vaccines and generate healthcare solutions which could be patented and commercialized afterwards. Hence, this paper identifies the factors which can reinforce the entrepreneurial insertion of universities and increase their capacity in supporting collective efforts aiming at combatting the COVID-19 aftermath. Idea: Based on a review of recent literature, the purpose of this conceptual study is twofold: identify the predictors and the success factors of academic entrepreneurship; and argue for research propositions that could guide future empirical research. In addition, this paper provides insights into the current evolution of the entrepreneurial experiences of Middle Eastern universities. Data: This explorative research was based on an extensive literature review of the core aspects relevant to academic entrepreneurship. Recent references published in peer-reviewed scholarly journals with the primary focus on the Middle East or other developing economies were targeted in order to build up the conceptual model revolving around nine research propositions. Tools: Selected references were reviewed and categorized around the mainstream themes identified by the authors, i.e., impact of entrepreneurial universities, antecedents of academic entrepreneurship, and its success factors. For each block, several research propositions were derived and presented. Findings: The literature review findings argue for the potential role that specific factors can play in promoting the entrepreneurial engagement of Middle Eastern universities, namely the national institutional framework, an easy access to funding sources, the existence of interrelations with local organizations and the quality of the university's organizational infrastructure. The conceptual framework assumes also that the performance of entrepreneurial universities would depend on the number and quality of relationships with the industry, the support of venture capitalists and the intensity of their entrepreneurial and market orientations. Contribution: This research contributes essentially in underlining the growing importance of academic entrepreneurship and how it can be a rewarding choice for Middle Eastern policy makers.

Keywords: entrepreneurial university, academic entrepreneurship, spin-offs, COVID-19, Middle East, venture capitalists JEL classification: I23, L26

\section{Introduction}

The evolving context of higher education encourages universities to adopt an entrepreneurial mindset, and this depends on the quality of the entrepreneurial capabilities of the personnel (Felgueira \& Rodrigues, 2020). The rising interest in entrepreneurial doctrine among universities originated from the changes in academic culture and environment which stresses upon the importance of creating value at all levels of activity (Urbano \& Guerrero, 2013). The creation of spin-offs helps universities commercializing their research outcomes and stimulate economic activity accordingly (Fini, Fu, Mathisen, Rasmussen, \& Wright, 2017).

*Corresponding author: Vladimir Dzenopoljac, e-mail: vladimir.dzenopoljac@aum.edu.kw 
The adoption of the Bayh-Dole Act in the United States in 1980 allowed universities to use their intellectual property rights to conduct entrepreneurial activities and link them with economic development (Guerrero \& Urbano, 2016).

Despite the considerable attention that universities are devoting to academic entrepreneurship (Bezanilla, García-Olalla, Paños-Castro, \& Arruti, 2020), they still face obstacles, i.e., knowledge filters, which restrain the effective dissemination of their knowledge into the economy (Audretsch, 2014; Hayter, 2013). Such spillovers are necessary to stimulate innovation and economic growth. As a result, universities started to adopt more entrepreneurial mindsets so they should facilitate the commercialization of their knowledge for a wider use in the society (Audretsch, 2014).

The concepts of Academic Entrepreneurship, or Entrepreneurial University, refer mainly to the creation of university spin-offs and academic start-ups with the knowledge and the intellectual property developed by academics (Cvijic, Tatarski, Katic, Vekic, \& Borocki, 2019; O'shea, Allen, Chevalier, \& Roche, 2005; Rodrigues, Ferreira, \& Felgueira, 2019). For instance, American universities are commercializing their knowledge and generating spin-offs of technology-intensive companies notably through the business ventures created by faculty. Those universities keep increasing their entrepreneurial commitment as they cumulate successful experience in managing their spin-offs. Also, public and private funding in science and engineering especially life science, chemistry and computer science disciplines, greatly supports those university spinoffs (O'shea et al., 2005). As a matter of fact, entrepreneurial universities display higher mobilization for research and cooperate more vigorously with the industry. They usually opt for unconventional approaches while effectively abiding by university policies (Cvijic et al., 2019).

Academics from higher educational institutions are classified into five categories based on their entrepreneurial behaviours: downers, achievers, followers, defenders, and rebels. Although their percentage is the smallest, Achievers are the most agile entrepreneurial type of academics. They are particularly committed to industry collaboration and research mobilization, which allows the extrapolation of knowledge creation and innovation to a larger scale. Achievers exceed other clusters also in regard to unconventionality and compliance with university policies (Rodrigues et al., 2019). This type of academics is the main driver of these spin offs and possess the highest importance in resolving the COVID-19 pandemic. Some of the main referenced research studies are mentioned in Table 1, with relation to the explored perspectives.

Table 1. Overview of related work

\begin{tabular}{|c|c|c|}
\hline Perspective explored & Studies & Main insights \\
\hline $\begin{array}{l}\text { Antecedents of } \\
\text { academic } \\
\text { entrepreneurship }\end{array}$ & $\begin{array}{l}\text { Shah, Shahjehan, \& Afsar (2019); } \\
\text { Bezanilla, García-Olalla, Guerrero } \\
\text { \& Urbano (2016); } \\
\text { Feola, Vesci, Botti, \& Parente } \\
\text { (2019); } \\
\text { Fini, Fu, Mathisen, Rasmussen, \& } \\
\text { Wright (2017); } \\
\text { Miranda, Chamorro-Mera, \& Rubio } \\
\text { (2017) }\end{array}$ & $\begin{array}{l}\text { The adoption of entrepreneurial activities } \\
\text { by universities depends essentially on } \\
\text { the existence of a risk-taking attitude and } \\
\text { a proactive mindset among internal } \\
\text { policy makers. Several other factors are } \\
\text { presented as predictors of academic } \\
\text { entrepreneurial intentions (e.g., } \\
\text { government support, involvement with } \\
\text { the industry, internal strategic and } \\
\text { organizational factors). }\end{array}$ \\
\hline $\begin{array}{l}\text { Creation of university } \\
\text { spin-offs }\end{array}$ & $\begin{array}{l}\text { Audretsch (2014); } \\
\text { Cvijic, Tatarski, Katic, Vekic, \& } \\
\text { Borocki (2019); } \\
\text { Fini, Fu, Mathisen, Rasmussen, \& } \\
\text { Wright (2017); } \\
\text { Guerrero \& Urbano (2016); } \\
\text { O'shea, Allen, Chevalier, \& Roche } \\
\text { (2005); } \\
\text { Rodrigues, Ferreira, \& Felgueira } \\
\text { (2019) }\end{array}$ & $\begin{array}{l}\text { Academic entrepreneurship takes place } \\
\text { through patenting and commercialization } \\
\text { of research outcomes. The } \\
\text { entrepreneurial engagement of } \\
\text { universities is predominantly led by } \\
\text { academic staff members. }\end{array}$ \\
\hline
\end{tabular}




\begin{tabular}{|c|c|c|}
\hline Perspective explored & Studies & Main insights \\
\hline $\begin{array}{l}\text { Contribution of } \\
\text { academic } \\
\text { entrepreneurship into } \\
\text { social and economic } \\
\text { development }\end{array}$ & $\begin{array}{l}\text { Aaboen, Laage-Hellman, Lind, } \\
\text { Öberg, \& Shih (2016); } \\
\text { Kawamorita, Salamzadeh, } \\
\text { Demiryurek, \& Ghajarzadeh } \\
\text { (2020); } \\
\text { Hayter (2013); } \\
\text { Miranda, Chamorro-Mera, \& Rubio } \\
\text { (2017); } \\
\text { Urbano \& Guerrero (2013) }\end{array}$ & $\begin{array}{l}\text { Academic entrepreneurship is likely to } \\
\text { stimulate the economic activity mainly } \\
\text { through technological spillovers and } \\
\text { knowledge dissemination. Collaborations } \\
\text { with local actors are portrayed as a key } \\
\text { characteristic of entrepreneurial } \\
\text { universities. }\end{array}$ \\
\hline $\begin{array}{l}\text { Success factors of } \\
\text { academic } \\
\text { entrepreneurship }\end{array}$ & $\begin{array}{l}\text { Franco-Leal, Camelo-Ordaz, } \\
\text { Fernandez-Alles, \& Sousa-Ginel } \\
\text { (2019); } \\
\text { Fuster, Padilla-Meléndez, Lockett, } \\
\text { \& del-Águila-Obra (2019); } \\
\text { Hayter (2013) }\end{array}$ & $\begin{array}{l}\text { Deep-seated networks with } \\
\text { entrepreneurs and industrials are likely to } \\
\text { support the success of university spin- } \\
\text { offs. Also, faculty previous } \\
\text { entrepreneurial and professional } \\
\text { experience is argued as a determinant } \\
\text { success factor. Finally, the role of } \\
\text { venture capitalists is suggested to } \\
\text { warrant the future growth of academic } \\
\text { entrepreneurial ventures. }\end{array}$ \\
\hline
\end{tabular}

Research has also demonstrated that the proactiveness of business schools' management is positively correlated with the entrepreneurial orientation of education institutions (Ball, 2019). Therefore, the aim of this conceptual research is to develop hypothetical propositions which could advise policy makers in the Middle East and other developing regions on how to enhance the entrepreneurial engagement of local universities as part of a large-scale response to COVID-19 repercussions. The emergency created by the pandemic has indeed caused a surge in the number of inventions in different nations including developing countries (Harris, Bhatti, Buckley, \& Sharma, 2020; Mathew \& Mathew, 2020). Universities - as other research institutes and pharmaceutical companies - were an integrative part of those initiatives. Numerous scientists were called upon by government officials to lead research groups on vaccines and remedies to stop the progression of the virus and heal the infected people. In addition, university scientists were keenly working on developing other sorts of solutions to support the forefront personnel who is directly combatting the virus, e.g., ventilators, masks, sterilization tools, rapid testers, etc.

The contributions of this research can be sensed in different aspects. Firstly, this manuscript is an attempt to highlight the significant impact that universities can have in regard to innovation efforts and national economic growth which are necessary during pandemic times. According to Cvijic et al. (2019), universities in developing countries need to abandon traditional research-based paradigms and embrace more entrepreneurial business models closely intertwined with the economic reality and likely to derive entrepreneurial activities initiated by academics (Cvijic et al., 2019). Additionally, our study provides important insights into the origins, the predictors, and the success factors of academic entrepreneurship. Those insights are recapitulated as research propositions which could serve as guidelines for effective management of entrepreneurial universities in the Middle East. The development of research propositions could serve as a basis for local policymakers to grasp their existing potential and promote consequently the culture of entrepreneurship beyond the mere education and training programmes delivered through universities and other institutions.

\section{The Entrepreneurial University as a Driver of Economic Growth and Competitiveness}

Entrepreneurial universities are at the centre of the concept of the quintuple helix which refers to the intensive cooperation between different actors in pursuit of highly impactful innovations. Those interrelations take place between universities, companies, governments, societies, and environments (Kawamorita, Salamzadeh, Demiryurek, \& Ghajarzadeh, 2020). As a matter of fact, entrepreneurial universities significantly contribute to regional socioeconomic development (Urbano \& Guerrero, 2013; Miranda, Chamorro-Mera, \& Rubio, 2017). Entrepreneurial universities act as a channel of knowledge dissemination and support economic growth and job creation (Hayter, 2013). The emergence of entrepreneurial universities mirrors the development of the role of the university which has evolved to align with the evolution of the economic system. The latter progressed indeed from an economy-based on the exploitation of physical resources to a knowledge-based economy, then into an entrepreneurial society. In this regard, entrepreneurial universities 
contribute to economic growth at two levels: creating new knowledge ("knowledge for its own sake") and generating spillovers through knowledge transfer and commercialization (Audretsch, 2014).

The universities nowadays play a significant role in achieving long-term sustainability goals, by being a crucial element in the quintuple helix innovation model (De la Vega Hernández \& Barcellos de Paula, 2019). More specifically, the role of entrepreneurial universities is visualized as transformative or as a "responsible facilitator" in the process of attaining these said goals (Gur, 2020). The economic impact of entrepreneurial universities manifests through three core activities, i.e., teaching, research, and entrepreneurship activities. While the outcomes of teaching are assessed through the employment rate, research output is measured by research collaborations, research contracts, consultancy, and income generated from facilities and intellectual property agreements. Spin-offs' ownership represents the main outcome from the entrepreneurial activity of universities. Four categories of ownership could be considered: active spin-offs owned by the university, active spin-offs not owned by the university, spin-offs owned by the staff, and spin-offs owned by graduates/alumni. In this sense, the entrepreneurship activities conducted by entrepreneurial universities have bigger economic impact than their teaching or research endeavours. Universities are considered to create three types of capital that positively affect gross domestic product of any country (Figure 1).

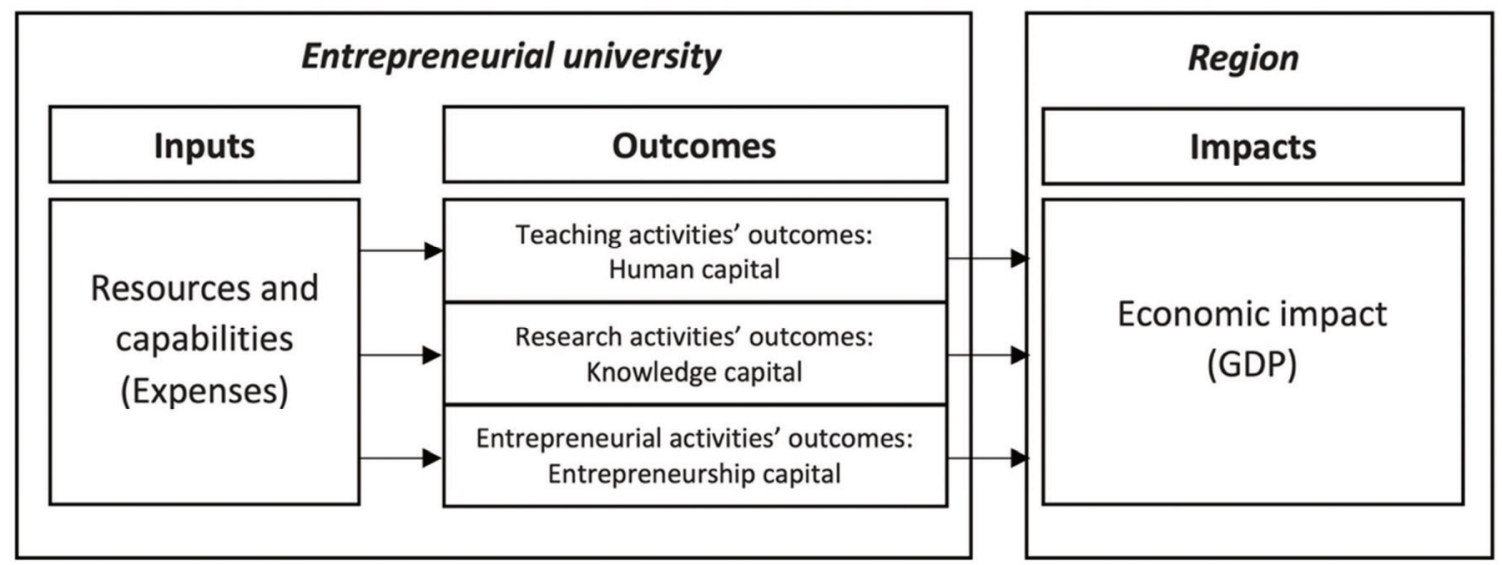

Figure 1. Impact of entrepreneurial universities on economy (Guerrero, Cunningham, \& Urbano, 2015)

These are human capital (created by universities' teaching activities), knowledge capital (accumulated through research activities of universities), and entrepreneurship capital (derived from entrepreneurial activities of universities) (Guerrero, Cunningham, \& Urbano, 2015). The effects of intellectual capital and knowledge on business performance and performance of the developing countries in the Middle East have been widely discussed and analyzed (e.g., Dzenopoljac, Alasadi, Zaim, \& Bontis, 2018; Dzenopoljac, Yaacoub, Elkanj, \& Bontis, 2017).

Aaboen, Laage-Hellman, Lind, Öberg, \& Shih (2016) attributed three different resource-interaction roles to university spin-offs within business networks, i.e., resource mediator, resource re-combiner and resource renewer. Those roles emphasize how university spin-offs pool their resources with those of their partners. Resource mediator implies that the spin-off entity acts as a 'bridge' connecting the different parties who could be research units, customers, suppliers, etc. Business partners do not adapt their processes and facilities accordingly while university spin-offs do. In the case of resource re-combiners, the university spinoffs supply their partners with more radical innovations which require substantive mutual adaptations based on resource re-combinations. Finally, when university spin-offs act as a resource renewer, this means that they develop disruptive solutions which challenge existing resource configurations and require, accordingly, the replacement of existing resources (renewal).

Finally, Guerrero, Urbano \& Fayolle (2016) proved the existence of a positive influence of the university's environmental factors on students' entrepreneurial activity and regional competitiveness. A university environment is composed of two factors, i.e., informal (such as attitudes, skills, actions, and role models) and formal (i.e., supportive infrastructure and specialized entrepreneurship programmes). The informal environmental factors have a bigger effect on entrepreneurial activity than the formal ones. In addition, the university's entrepreneurial activity exerts a positive effect on regional competitiveness - mainly with regards to the social aspects of competitiveness (Guerrero et al., 2016). Thus, the first research proposition is as follows:

Research Proposition 1: The emergence and development of entrepreneurial universities can contribute to economic growth, national competitiveness, and innovative activity. 


\section{Origins and Predictors of Academic Entrepreneurship}

Shah, Shahjehan, \& Afsar (2019) suggest that the emergence of an entrepreneurially oriented culture in a university depends on different internal factors, such as the risk tolerance, the attitude towards failure, trust and proactiveness in addressing market opportunities. Nonetheless, structural changes are necessary to allow such a culture to emerge, e.g., reducing bureaucracy and promoting delegation of power. Undertaking changes at the strategic level can also contribute to reinforcing entrepreneurial culture at universities (Shah et al., 2019).

In fact, research shows the existence of a correlation between the factors underlying entrepreneurial universities, such as the 'legal and administrative context' (when government and public administration are involved in and facilitate entrepreneurship); 'business and organizational context' (interacting with nearby organizations belonging to the same sector); 'resource factors' (funding for entrepreneurship and training in entrepreneurship for faculty); mission, strategy and policies; organizational design; training and research in entrepreneurship and extra-curricular training; inclusion of professionals from businesses and organizations in the development and delivery of the curriculum; and support from the management team (Bezanilla et al., 2020).

Building on the theory of planned behavior, Feola, Vesci, Botti, \& Parente (2019) investigated the determinants of academic entrepreneurial intentions among Italian university researchers and found that they are positively influenced by psychological variables (attitude towards subjective norms and perceived behavioural control). The same study also revealed the influence of contextual factors on academic entrepreneurial intentions, namely the government support (negative effect), and the industrial and financial support (positive effect). The attitude is positively determined by both government support and university support. The authors attributed the surprising negative effect of government support on academic entrepreneurial intentions to the 'bureaucracy and inefficiencies' of the of the Italian public administration (Feola et al., 2019).

Building also on the theory of planned behaviour, Miranda et al. (2017) have demonstrated that the attitude towards entrepreneurship is the sole direct predictor of academic entrepreneurial intentions among Spanish university academics. This predictor is in turn influenced by the perceived utility, business experience and creativity. Subjective norms and perceived control have no effect on entrepreneurial intentions of Spanish academics. The authors believe that their findings stress upon the prominent role of personality traits in the establishment of academic spin-offs (Miranda et al., 2017).

Fini et al. (2017) applied the institutional theory to explore the power of institutional changes in generating university spin-offs. They found that adapting the legislation at the national and the university levels were conducive to higher rates of academic spin-offs. More specifically, the number of spin-off creations is positively affected by the legislative changes aiming at enhancing intellectual property protection (national level) and the establishment of technology transfer offices at the university level. However, the increase of institutional changes is likely to install a climate of uncertainty which is likely to dissuade venture capitalists from supporting academic spin-offs. Thus, institutional changes lead to lower quality of university spin-offs (Fini et al., 2017).

In their explorative theoretical essay, Guerrero \& Urbano (2016) constructed a model in which they argued in favour of the role of country-level factors and organizational factors in supporting the outcomes of university activities including teaching, research, and entrepreneurship. They consider the institutional context as the main country-level factor and this comprises the political, legal, and cultural characteristics of a nation. Country-level factors are expected to shape the organization-level dimensions, such as university's structure, incentives, education approach, role models, community attitudes towards the institution, workforce, reputation, partnerships, and facilities. As the conclusion of given predictors of academic entrepreneurship, we derive additional four research propositions:

Research Proposition 2: The evolution of the national institutional framework with respect to the protection of intellectual property rights will encourage the emergence and development of entrepreneurial universities in the Middle East.

Research Proposition 3: The ease of access to funding sources at the national level (governmental agencies, venture capitalists, banks, etc.) will encourage the emergence and development of entrepreneurial universities in the Middle East.

Research Proposition 4: The interrelations with local organizations will encourage the emergence and development of entrepreneurial universities in the Middle East. 
Research Proposition 5: The existence of appropriate university environmental factors (education approach, role models, funding for entrepreneurship and training in entrepreneurship for faculty, establishment of technology transfer offices, etc.) will encourage the emergence and development of entrepreneurial universities in the Middle East.

\section{Success Factors of Academic Entrepreneurship}

As much as the entrepreneurial ecosystem is strengthened by the proliferation of academic entrepreneurship, it plays a positive role in the performance of university spin-offs in return. In particular, the institutional and social aspects of this entrepreneurial ecosystem are highly impactful. While the institutional context affects to a bigger extent the university spin-off during the stage of creation and initial development, the influence of the social context - referring mainly to the networks with entrepreneurs and industrials - is stronger in the stage of consolidation (Franco-Leal, Camelo-Ordaz, Fernandez-Alles, \& Sousa-Ginel, 2019).

Hayter (2013) outlined three ranges of factors which determine the spin-off success in technology commercialization. Those factors are related either to the entrepreneur (mainly faculty members), the university, or the firm. First, faculty members who are engaged in consulting services with the industry are more likely to commercialize their spin-off knowledge. However, facultys' previous experience in spin-off creation does not affect their future entrepreneurial success. Also, faculties that conduct industrial research and development achieve negative results in terms of technology commercialization. University-related factors have limited effect on spin-off success. More specifically, university equity investments and technology licensing offices do not affect spin-off success. The commercialization success is less likely to happen when the spin-offs rely on the university entrepreneurship services. Finally, firm-specific success factors comprise several aspects such as the appointment of non-faculty CEO, the financial resources provided by venture capitalists, the participation in joint ventures, and the acquisition of external intellectual property rights, i.e., open innovation (Hayter, 2013).

Furthermore, university-focused venture capitalists seem to play a focal role in the ecosystem of the entrepreneurial universities as they help in reinforcing the relationships of those institutions with the spin-offs, contributing therefore to their long-term success (Fuster, Padilla-Meléndez, Lockett, \& del-Águila-Obra, 2019). These are referred to as financial intermediaries which "are located close to universities, have a strong focus on research exploitation and are continually looking for new potential technology in which to invest" (Fuster et al., 2019, p.3). Here, Urbano \& Guerrero (2013) contend that entrepreneurial universities need to contribute to building a stronger entrepreneurial ecosystem, inside and outside the university realms, within existing firms.

Internally, the performance of university spin-offs depends on the adoption of stronger entrepreneurial and market orientations, which refers respectively to entrepreneurial posture and sensitivity towards the market (Migliori, Pittino, Consorti, \& Lucianetti, 2019). The last four research propositions are formulated as follows:

Research Proposition 6: The performance of the spin-offs created by entrepreneurial universities can be supported by the number and quality of relationships with the industry at multiple levels (non-faculty CEO, joint ventures created with companies, faculty experience in consulting, etc.).

Research Proposition 7: The performance of the spin-offs created by entrepreneurial universities can be supported by the role played by venture capitalists.

Research Proposition 8: The performance of the spin-offs created by entrepreneurial universities can be supported by the intensity of their entrepreneurial orientation.

Research Proposition 9: The performance of the spin-offs created by entrepreneurial universities can be supported by the intensity of their market orientation.

\section{The Reality of Academic Entrepreneurship in COVID-19 Era in Emerging Countries and the Middle East in Particular}

The global COVID-19 pandemic was declared in March 2020 by the World Health Organization (WHO). This occurrence has affected the world both economically and socially. In terms of entrepreneurial action in general, one question that appeared was whether quality planning processes could have prevented the economic damage to a certain extent (Giones, Brem, Pollack, Michaelis, Klyver, \& Brinckmann, 2020). 
Additionally, the mentioned research study assessed entrepreneurial action in a crisis context using the highlights from planning, frugality, and emotional support research, and tried to determine how entrepreneurs adapted to new circumstances. The entire research shed light on entrepreneurs' reaction to crisis by applying disaster management framework introduced by Lettieri, Masella, \& Radaelli (2009). In terms of COVID-19 pandemic, entrepreneurs are facing dual challenge: how to survive and how to innovate. Entrepreneurial universities are even more significant in this regard because they bridge the gap between the fundamental research, which is one of the key tools for fighting the unprecedented pandemic and applied research and development. According to Kirby, Guerrero, \& Urbano (2011), an entrepreneurial university is a natural incubator that attempts to simultaneously fulfil its missions in terms of teaching, research, and entrepreneurial activities, while providing suitable atmosphere in which the university community (academics, students, and staff) can identify, explore, and exploit innovative and creative ideas that could be transformed into new ventures. On the other hand, the global COVID-19 pandemic placed major obstacles on the entrepreneurial universities and disabled an important side of this form of education, which is learning through practical and real-life examples (Ratten, 2020).

The COVID-19 pandemic has triggered several scientific innovations all over the world including developing countries (Harris et al., 2020; Mathew \& Mathew, 2020). These innovations helped in designing artificial breathing devices, healthcare patient diagnosis and monitoring tools, protective equipment for medical staff and other information technology tools used for education and tracking purposes (Mathew \& Mathew, 2020). Some of these innovations were called "frugal innovations" as they mean doing more with less under the pressure and urgency exerted by the pandemic (Harris et al., 2020).

Despite the shortage in healthcare infrastructure in their country, Ghanaian scientists were among the earliest to sequence the COVID-19 genome. The University of Ghana Noguchi Memorial Institute for Medical Research was able to put forward a novel 'pool testing technique' which allowed the country to significantly increase the number of tests. Also, collaboration between Kwame Nkrumah University of Science and Technology with the Kumasi Centre for Collaborative Research and Incas Diagnostics led to the development of rapid diagnostic test kits and ventilators (Sibiri, Zankawah, \& Prah, 2020).

With respect to the situation in the Middle East, a qualitative study was conducted by Kawamorita et al. (2020) to identify the main challenges affecting entrepreneurial universities during the COVID-19 crisis in that region. The findings of the study reveal that the major challenges concern the decreasing public and private funding, the reduced opportunities for face-to-face networking, the management of technology transfer offices as well as the startup accelerators and incubators (Kawamorita et al., 2020). Universities in general represent institutions that support economies and promote social well-being (Ratten, 2017). The COVID-19 pandemic created restrictions on everyday life never before witnessed. The freedom of movement has decreased due to lockdowns and imposed curfews, schools and universities shut their doors and moved to online classes delivery. According to Martin and Turner (2010), during the times of crises, more universities need to act in entrepreneurial manner. This includes being alert and more adaptive to external challenges. The current crisis has posed certain financial and funding limitations on universities, but it also creates opportunities for entrepreneurial universities. The universities have adapted quickly to online class delivery and are constantly innovating the ways in which they can increase in-class engagement. Furthermore, Wenzel, Stanske, \& Lieberman (2020) argue that there are four ways organizations respond to a crisis: retrenchment, persevering, innovating and exit. The only available solution for universities is innovating. In this regard, universities showed responsiveness to the COVID-19 crisis and created the opportunity for those universities that are teaching entrepreneurship to "walk the talk" and to engage in fighting the crisis through student and faculty innovation and entrepreneurial ventures.

In the Middle East, universities reacted to COVID-19 pandemic in a mild way. For example, in the Middle East College Oman, the reaction was a simple and straightforward move towards emergency remote teaching, using various software tools (Mohammed, Khidhir, \& Nazeer, 2020). A majority of the universities in the Middle East have reacted similarly to the Middle East College Oman, which aligns well with persevering crisis reaction as stated by Wenzel et al. (2020). The response to this crisis was expected to be more proactive, as there are examples of truly entrepreneurially oriented universities in this region, analyzed by Guerrero, Urbano, \& Salamzadeh (2014). The University of Tehran and Sharif University of Technology were found as the ones qualifying to be entrepreneurial according to the following criteria: (1) universities are located in regions characterized by higher levels of entrepreneurship measured by the number of new enterprises; (2) universities that promote entrepreneurial culture in their strategic actions that allow adaptation to environmental changes; (3) universities that show their self-instituting efforts to change their general character, by developing entrepreneurial initiatives with outcomes such as patents, licenses, spin-offs and research agreements; and (4) universities in the first-position rankings such as Webometrics (Guerrero et al., 2014). 
Apart from the mentioned research studies, there is a paucity of scholarship work about Middle Eastern academic entrepreneurship experience, especially during COVID-19 pandemic. As proposed earlier by Kawamorita et al. (2020), the major challenges in this regard are the decreasing public and private funding, the reduced opportunities for face-to-face networking, the management of technology transfer offices as well as the startup accelerators and incubators. Additionally, universities in the Middle Eastern region have shorter academic and research history, in comparison with the United States, or Europe. Due to shorter history, these academic institutions in the region have not been able to properly develop their entrepreneurial focus yet. As regards the ongoing COVID-19 pandemic, similarly to entrepreneurs, entrepreneurial universities face similar choices: they can innovate or persevere.

Conclusion

The presented conceptual research has the sole purpose of addressing the apparent gap in the literature in the area of academic entrepreneurship in the Middle East region. The literature review into the matter revealed that the emergence and development of entrepreneurial universities could contribute to economic growth, national competitiveness, and innovative activity. One such empirical evidence can be found in the work of Guerrero et al. (2015). Since the absence of academic entrepreneurship in the Middle East is evident, this research proposal points to the important possible framework that could positively affect the development of entrepreneurial universities. As shown by Fini et al. (2017) who applied the institutional theory to explore the power of institutional changes in generating university spin-offs, the number of spin-off creations is positively affected by the legislative changes aiming at enhancing intellectual property protection (national level) and the establishment of technology transfer offices at the university level. This research proposition is also valid for the context of universities in the Middle East.

Guerrero \& Urbano (2016) used a model in which it was determined that country-level factors and organizational factors are important in supporting the outcomes of university activities including teaching, research, and entrepreneurship. They consider the institutional context as the main country-level factor and this comprises the political, legal, and cultural characteristics of a nation. Country-level factors are expected to shape the organizational-level variables which include two dimensions, i.e., university environmental factors (structure, incentives, education approach, role models, and community attitudes towards the institution) and internal factors (workforce, reputation, partnerships, and facilities). Also, in the existing framework within the Middle Eastern countries, the ease of access to funding sources at the national level (governmental agencies, venture capitalists, banks, etc.) can encourage the emergence and development of entrepreneurial universities.

As stated by Hayter (2013), many factors affect the success of university spin-offs. Those factors are related either to the entrepreneur (mainly university scientists), the university, or the firm. Also, university-focused venture capitalists play an important role in development of entrepreneurship ecosystem within universities (Fuster et al., 2019). In this regard, the performance of the spin-offs created by entrepreneurial universities may be supported by the number and quality of relationships with the industry at multiple levels (non-faculty CEO, joint ventures created with companies, faculty experience in consulting, etc.), as well as by the role played by venture capitalists. Finally, in order to develop the climate for thriving of the entrepreneurial activities in the Middle East, universities need to adapt entrepreneurial and market orientation, which are instilled by the management of universities as well as the university's exposure to industry collaboration and consultancy.

In view of the avenues of future research, it is vital to note that many universities in the Middle East are considering themselves as self-sufficient entities, which gives space for improvements in research. One of the possibilities is to develop quality interrelations with local organizations, which may encourage the emergence and development of entrepreneurial universities and research opportunities in this area. In relation with this, higher education framework in the Middle East lacks more quality education approach, role models, funding for entrepreneurship and training in entrepreneurship for faculty. All of these areas can be significantly enhanced with quality research that would address teaching entrepreneurship in higher education, focusing on case study approach considering success startup stories in the region, and ultimately developing high quality entrepreneurial universities that would foster the development of this engaging academic field and economy as a whole. 


\section{REFERENCES}

[1] Aaboen, L., Laage-Hellman, J., Lind, F., Öberg, C., \& Shih, T. (2016). Exploring the roles of university spin-offs in business networks. Industrial Marketing Management, 59, 157-166. DOI:10.1016/j.indmarman.2016.03.008

[2] Audretsch, D. B. (2014). From the entrepreneurial university to the university for the entrepreneurial society. The Journal of Technology Transfer, 39(3), 313-321. DOI:10.1007/s10961-012-9288-1

[3] Ball, M. J. (2019). The Relationship Between Entrepreneurial Orientation and School Business Performance through the Lens of Rural K-12 Public Chief School Business Officials (Unpublished PhD's thesis). St. John Fisher College, New York, The United States of America.

[4] Bezanilla, M.J., García-Olalla, A., Paños-Castro, J., \& Arruti, A. (2020). Developing the Entrepreneurial University: Factors of Influence. Sustainability, 12(3), 842. DOI: 10.3390/su12030842

[5] Cvijic, M., Tatarski, J., Katic, I., Vekic, A., \& Borocki, J. (2019). Entrepreneurial orientation of public universities in republic of Serbia-empirical study. Sustainability, 11(6), 1509-1522. DOI: $10.3390 /$ su11061509

[6] De la Vega Hernández, I.M. \& Barcellos de Paula, L. (2019). The quintuple helix innovation model and brain circulation in central, emerging and peripheral countries. Kybernetes, 49(9), 2241-2262. DOI: 10.1108/K-08-2019-0522

[7] Dzenopoljac, V., Alasadi, R., Zaim, H., \& Bontis, N. (2018). Impact of knowledge management processes on business performance: Evidence from Kuwait. Knowledge and Process Management, 25(2), 1-11. DOI: $10.1002 / \mathrm{kpm} .1562$

[8] Dzenopoljac, V., Yaacoub, C., Elkanj, N., \& Bontis, N. (2017). Impact of intellectual capital on corporate performance: evidence from the Arab region. Journal of Intellectual Capital, 18(4), 884-903. DOI: 10.1108/JIC-01-2017-0014

[9] Felgueira, T., \& Rodrigues, R. G. (2020). I-ENTRE-U: an individual entrepreneurial orientation scale for teachers and researchers in higher education institutions. International Review on Public and Nonprofit Marketing, 17(1), 1-21. DOI: 10.1007/s12208-019-00226-2

[10] Feola, R., Vesci, M., Botti, A., \& Parente, R. (2019). The determinants of entrepreneurial intention of young researchers: Combining the theory of planned behavior with the triple Helix model. Journal of Small Business Management, 57(4), 1424-1443. DOI: 10.1111/jsbm.12361

[11] Fini, R., Fu, K., Mathisen, M. T., Rasmussen, E., \& Wright, M. (2017). Institutional determinants of university spin-off quantity and quality: a longitudinal, multilevel, cross-country study. Small Business Economics, 48(2), 361-391. DOI: 10.1007/s11187-016-9779-9

[12] Franco-Leal, N., Camelo-Ordaz, C., Fernandez-Alles, M., \& Sousa-Ginel, E. (2019). The Entrepreneurial Ecosystem: Actors and Performance in Different Stages of Evolution of Academic Spin-offs. Entrepreneurship Research Journal, 10(2), 1-20. DOI: 10.1515/erj-2018-0228

[13] Fuster, E., Padilla-Meléndez, A., Lockett, N., \& del-Águila-Obra, A. R. (2019). The emerging role of university spin-off companies in developing regional entrepreneurial university ecosystems: The case of Andalusia. Technological Forecasting and Social Change, 141, 219-231. DOI: 10.1016/j.techfore.2018.10.020

[14] Giones, F., Brem, A., Pollack, J. M., Michaelis, T. M., Klyver, K., \& Brinckmann, J. (2020). Revising entrepreneurial action in response to exogenous shocks: Considering the COVID-19 pandemic. Journal of Business Venturing Insights. 14, 1-7, DOI: 10.1016/j.jbvi.2020.e00186

[15] Guerrero, M., Cunningham, J. A., \& Urbano, D. (2015). Economic impact of entrepreneurial universities' activities: An exploratory study of the United Kingdom. Research Policy, 44(3), 748-764. DOI: 10.1016/j.respol.2014.10.008

[16] Guerrero M., \& Urbano D. (2016). The Transformative Role of Universities: Determinants, Impacts, and Challenges. In J. Leitão \& H. Alves (Eds.), Entrepreneurial and Innovative Practices in Public Institutions. Applying Quality of Life Research (Best Practices), (pp 1-17). Cham: Springer.

[17] Guerrero, M., Urbano, D., \& Fayolle, A. (2016). Entrepreneurial activity and regional competitiveness: evidence from European entrepreneurial universities. The Journal of Technology Transfer, 41(1), 105131. DOI: $10.1007 / \mathrm{s} 10961-014-9377-4$

[18] Guerrero, M., Urbano, D., \& Salamzadeh, A. (2014). Evolving entrepreneurial universities: experiences and challenges in the Middle Eastern context. In A. Fayolle and D. T. Redford (Eds.), Handbook of Research in Entrepreneurship Education: Entrepreneurial University Handbook, (pp. 163-187). Cambridge: Edward Elgar Publishing.

[19] Gur, U. (2020). Transformative university in quadruple helix sustainability governance. In Leitão, J., Ratten, V., \& Barroca, J. (Eds.), A Guide to Planning and Managing Open Innovative Ecosystems, (pp. 41-55). Emerald Publishing Limited, DOI: 10.1108/978-1-78973-409-620201004

[20] Harris, M., Bhatti, Y., Buckley, J., \& Sharma, D. (2020). Fast and frugal innovations in response to the COVID-19 pandemic. Nature Medicine, 26, 814-817. DOI: 10.1038/s41591-020-0889-1 
[21] Hayter, C. S. (2013). Harnessing university entrepreneurship for economic growth: Factors of success among university spin-offs. Economic Development Quarterly, 27(1), 18-28. DOI: $10.1177 / 0891242412471845$

[22] Kawamorita, H., Salamzadeh, A., Demiryurek, K., \& Ghajarzadeh, M. (2020). Entrepreneurial Universities in Times of Crisis: Case of Covid-19 Pandemic. Journal of Entrepreneurship, Business and Economics, 8(1), 77-88. Retrieved from

[23] Kirby, D.A., Guerrero, M., \& Urbano, D. (2011). The theoretical and empirical side of entrepreneurial universities: An institutional approach. Canadian Journal of Administrative Sciences, 28(3), 302-16.

[24] Lettieri, E., Masella, C., \& Radaelli, G. (2009). Disaster management: findings from a systematic review. Disaster Prevention and Management. 18(2), 117-136. DOI: 10.1108/09653560910953207

[25] Martin, L., \& Turner, P. (2010). Entrepreneurial universities - the key ingredient in the recipe for UK innovation?, The International Journal of Entrepreneurship and Innovation, 11(4), 273-281.

[26] Mathew, J. L., \& Mathew, T. L. (2020). Invention, Innovation, and Imitation in India-Necessity Arising from the COVID-19 Pandemic. Annals of the National Academy of Medical Sciences (India). 56(2), 7786. DOI: $10.1055 / \mathrm{s}-0040-1713719$

[27] Migliori, S., Pittino, D., Consorti, A., \& Lucianetti, L. (2019). The relationship between Entrepreneurial Orientation, Market Orientation and Performance in University Spin-Offs. International Entrepreneurship and Management Journal, 15, 793-814. DOI: 10.1007/s11365-017-0488-x

[28] Miranda, F. J., Chamorro-Mera, A., \& Rubio, S. (2017). Academic entrepreneurship in Spanish universities: An analysis of the determinants of entrepreneurial intention. European Research on Management and Business Economics, 23(2), 113-122. DOI: 10.1016/j.iedeen.2017.01.001

[29] Mohammed, A. O., Khidhir, B. A., \& Nazeer, A. (2020). Emergency remote teaching during Coronavirus pandemic: the current trend and future directive at Middle East College Oman. Innovative Infrastructure Solutions, 5(72), 1-11, DOI: 10.1007/s41062-020-00326-7

[30] O'shea, R. P., Allen, T. J., Chevalier, A., \& Roche, F. (2005). Entrepreneurial orientation, technology transfer and spin-off performance of US universities. Research Policy, 34(7), 994-1009. DOI: $10.1177 / 0891242412471845$

[31] Ratten, V. (2017). Entrepreneurial universities: the role of communities, people and places. Journal of Enterprising Communities: People and Places in the Global Economy, 11 (3), 310-315.

[32] Ratten, V. (2020). Coronavirus (Covid-19) and the entrepreneurship education community. Journal of Enterprising Communities: People and Places in the Global Economy, 14(5), 753-764. DOI: 10.1108/JEC-06-2020-0121

[33] Rodrigues, R.G., Ferreira, J.J.M., \& Felgueira, T. (2019). Entrepreneurial academics: a taxonomy with Latent Profile Analysis. Management Decision, 57(12), 3346-3363. DOI: 10.1108/MD-10-2018-1157

[34] Sibiri, H., Zankawah, S. M., \& Prah, D. (2020). Coronavirus diseases 2019 (COVID-19) response: Highlights of Ghana's scientific and technological innovativeness and breakthroughs. Ethics, Medicine and Public Health, 14, 100537. DOI: 10.1016/j.jemep.2020.100537

[35] Shah, S.I., Shahjehan, A., \& Afsar, B. (2019). Determinants of Entrepreneurial University Culture Under Unfavorable Conditions: Findings from a Developing Country. Higher Education Policy, 32(2), 249-271. DOI: $10.1057 / \mathrm{s} 41307-018-0083-y$

[36] Urbano, D., \& Guerrero, M. (2013). Entrepreneurial universities: Socioeconomic impacts of academic entrepreneurship in a European region. Economic development quarterly, 27(1), 40-55. DOI: $10.1177 / 0891242412471973$

[37] Wenzel, M., Stanske, S., \& Lieberman, M. (2020). Strategic responses to crisis. Strategic Management Journal, 41, V7-V18. 


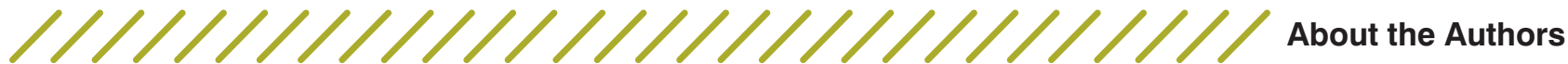

\author{
Oualid Abidi \\ School of Business, Australian College of Kuwait \\ o.abidi@ack.edu.kw
}

Dr. Oualid Abidi has a Ph.D. in Administrative Sciences from Université Laval (Canada, October 2011). He also holds a Master's Degree in Project Management from Université du Québec à Trois-Rivières (Canada, 2005), and a Bachelor degree in Finance completed in 2002 at Institut Supérieur de Gestion de Tunis in Tunisia. Dr. Oualid Abidi is serving currently as associate professor of management at the Australian College of Kuwait since February 2021. Prior to that appointment, he held several teaching and administrative positions at higher academic institutions in Kuwait and Canada.

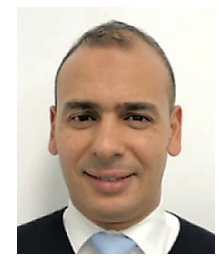

\section{College of Business and Economics, United Arab Emirates University vladimir.dzenopoljac@gmail.com}

Vladimir Dzenopoljac is an associate professor of Strategic Management at the College of Business and Economics, na United Arab Emirates University, UAE. Before this, he was associate professor at College of Business Administration within American

University of the Middle East in Kuwait. He received his PhD Degree from the University of Kragujevac, Serbia, in the field of impact of intellectual capital on value creation incontemporary enterprises. Alongside his academic career, Vladimir providedconsultancy services in the fields of strategy development and execution,business planning, and financial planning and analysis. He has published a significantnumber of research papers in his field of professional expertise and has beeninvolved in implementation of several projects for small, medium, and big companies. His areas of professional interest are strategic financial managementand intellectual capital management.

\section{Aleksandra Dzenopoljac Independent researcher aleksandra.dzenopoljac@gmail.com}

Aleksandra Dzenopoljac is an independent researcher and industry practitioner with extensive corporate experience in areas such as marketing, human resource management, strategic and business planning, as well as in the field of supply chain management. Aleksandra received her bachelor and master's degrees from the University of Kragujevac, Serbia, in the field of Marketing. In the last 15 years, she has occupied junior and senior managerial positions in companies in logistics, manufacturing, and entertainment industries.
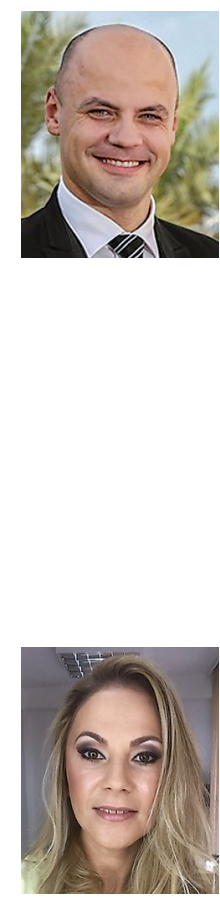